\title{
Pengaruh penambahan kitosan sisik ikan papuyu (Anabas testudienus) terhadap sifat kimia, mekanik dan struktur morfologi pada edible film pati jagung
}

\author{
Maria Natalia ${ }^{1}$, Yuli Ristianingsih*2 \\ 1Jurusan Teknik Kimia Universitas Lambung Mangkurat \\ Jl.A.Yani KM 36 Banjar Baru, Kalimantan Selatan \\ Jurusan Teknik Kimia Universitas Pembangunan Nasional "Veteran" Yogyakarta \\ J1.SWK 104 (Lingkar Utara) Condong Catur, Yogyakarta 55283 \\ e-mail: *y.ristianingsih@upnyk.ac.id
}

Diterima: 31 Oktober 2019 / Disetujui: 31 Desember 2019 / Dipublikasi online: 31 Desember 2019 DOI: https://doi.org/10.22437/chp.v4i2.7959

\begin{abstract}
ABSTRAK
Tujuan penelitian ini adalah untuk mengetahui pengaruh penambahan kitosan ikan papuyu terhadap sifat kimia, mekanik dan struktur morfologi pada edible film pati jagung. Ikatan molekul antara pati jagung dan kitosan mempengaruhi kuat tarik edible film. Sifat kimia dari edible film dapat dilihat dengan uji FTIR. Sedangkan sifat mekanik dapat diketahui dengan uji kuat tarik. Analisis yang telah dilakukan diketahui bahwa sifat kimia edible film melalui analisa gugus fungsional (FT-IR) menunjukkan bahwa edible film mengandung gugus $\mathrm{OH}$ (pati) dan $C=H$ (kitosan). Analisis kuat tarik menunjukkan bahwa penambahan kitosan mampu meningkatkan nilai kuat tarik edible film dengan nilai maksimum kuat tarik 14,5 MPa. Nilai elastisitas pada kosentrasi kitosan 2\% mengalami penurunan dan nilai maksimum EAB 6,3\%. Struktur morfologi pada edible film pada konsentrasi kitosan 2\% diketahui bahwa kitosan tercampur merata. Kuat tarik dan struktur morfologi merupakan aspek yang penting dalam edible film untuk menentukan kualitas bahan pengemas sebelum dikomersilkan.
\end{abstract}

Kata kunci: edible film, pati jagung, kitosan, kuat tarik, struktur morfologi

\begin{abstract}
The aimed of this research was to known effect added of chitosan papuyu fish scales determine chemical, mechanical properties and structure morphological of edible film. Chemical properties of edible film could be seen by FTIR analysis. Mechanical properties could be seen by tensile strength test. Molecular bond between cornstarch and chitosan influences the tensile strength of edible films. FTIR analysis shown that edible film contain group $\mathrm{OH}$ of starch and $\mathrm{C}=\mathrm{H}$ of chitosan. Tensile strength analysis shown that addition chitosan able to improve value of tensile strength edible film with maximum value of tensile strength 14,5 MPa. Value of elongation at break at concentration chitosan 2\% has decrease and maximum value EAB 6,3\%. Structure morphology of edible film concentration chitosan 2\% shown that chitosan mixed well. Tensile strength and structure morphology has been an important aspect of edible film to determine quality of material packaging before commercializing.
\end{abstract}

Keywords: edible film, corn starch, chitosan, tensile strength, morphological structure 


\section{PENDAHULUAN}

Polimer sintetis yang berasal dari petroleum seperti polietilen dan polivinil klorida biasa digunakan sebagai bahan pengemas karena sifat termomekanikal yang baik dan harga yang ekonomis. Tetapi bahan tersebut tidak biodegradable (Yang, 2008). Selain itu, pengemas sintetis dari petroleum tersebut menghasilkan polusi, racun dan sampah karena tidak mampu terurai dalam tanah (Othman, 2014). Untuk mengatasi permasalahan tersebut maka pengunaan komersial bahan pengemas berbasis bio atau ramah lingkungan diimplementasikan. Potensi biopolimer seperti pati, selulosa, kitosan dan gelatin diminati peneliti karena sifat natural yang dimiliki seperti biodegradable, terbarukan dan mengandung bahan aktif yang dapat berperan sebagai antibacterial agent, antioksida dan biosensor (Imran, 2010).

Pati merupakan polimer alami yang sangat melimpah dan bahan pengemas makanan yang menjanjikan karena terbarukan, biodegradable, dapat dimakan dan ekonomis. Selain itu, pati memiliki sifat penghalang oksigen yang sangat baik (Forssell, 2002). Pati jagung diketahui memiliki kandungan amilosa lebih tinggi daripada jenis pati yang lainnya seperti pati kentang dan gandum yaitu sekitar 25\%. Pati dengan kandungan amilosa yang lebih tinggi memiliki sifat penghalang, ketahanan kelembapan dan sifat mekanik yang rendah (Basiak et al., 2017). Penambahan plasticizer diperlukan untuk meningkatkan elastisitas film. Gliserol diketahui merupakan pemplastis yang baik dalam proses pembentukan film sebagai stabilitas dan kompatibilitas dengan sumber daya hayati yang digunakan dalam sistem pengemasan. Namun, film berbasis pati memiliki kekurangan pada kelarutan air dan daya serap uap air (Antoniou et al., 2015). Maka film dapat dicampurkan dengan biopolimer alami seperti kitosan untuk memperbaiki kekurangan tersebut (Mathew, 2008). Kitosan memiliki kemampuan sebagai agen penguat untuk meningkatkan kuat tarik, biokompatibilitas, biodegradable dan sifat antimikroba (Dutta, 2009). Sifat polikationik pada kitosan memberikan kemungkinan pada pembentukan film dengan pemecahan segmen polimer dan selanjutnya pembentukan kembali rantai polimer menjadi matriks atau gel film. Hal ini dapat dicapai melalui penguapan pelarut sehingga menciptakan ikatan silang ionik (Fernandez-Saiz, 2009). Kitosan ikan papuyu memiliki derajat deasetilasi sebesar 97,48\% yang mana lebih tinggi dibandingkan dengan kitosan udang (Asnia, 2017). Penelitian yang dilakukan (Othman, 2016) edible film dari pati tapioka dan kitosan dengan 
variasi kitosan 60\% menghasilkan kuat tarik senilai 21,23 $\mathrm{MPa}$ dan elastisitasnya senilai $2,52 \%$. Sedangkan, edible film berbasis pati jagung dan kitosan dengan konsentrasi $61 \%$ memiliki kuat tarik dengan nilai 6,5 $\mathrm{MPa}$ dan elastisitasnya 125\% (Ren, 2017). Maka penelitian ini dilakukan untuk mengetahui pengaruh penambahan kitosan ikan papuyu pada sifat fisik, mekanik dan morfologi edible film dengan variasi kitosan 0,5\% sampai $2 \%$.

\section{METODOLOGI PENELITIAN}

\section{Alat dan Bahan}

Pembuatan biofilm pada penelitian ini menggunakan alat-alat laboratorium seperti gelas beker, neraca analitik, gelas ukur, magnetic stirrer, oven, kertas saring, blender, hotplate, termometer, cetakan kaca, ayakan 20 mesh, gunting, cutter, spatula, pengaduk kaca dan gelas arloji, Torsee's Electronic System Universal Testing Machine dan SEM JEOL JSM-6360LA.

Bahan baku untuk pembuatan bio film adalah pati jagung merk Maizena. Sedangkan sisik ikan papuyu digunakan sebagai bahan baku untuk pembuatan kitosan. Selain itu, pada penelitian ini juga digunakan bahan kimia pendukung seperti: gliserol $\left(\mathrm{C}_{3} \mathrm{H}_{8} \mathrm{O}_{3}\right), \mathrm{NaOH}, \mathrm{HCl}, \mathrm{CH}_{3} \mathrm{COOH}$ dan aquadest.

\section{Pembuatan Kitosan dari Sisik Ikan Papuyu}

Pada pembuatan kitosan, sisik ikan papuyu sebelumnya dicuci dan dikeringkan di bawah sinar matahari selama 3 hari. Setelah kering, sisik ikan papuyu ditumbuk hingga halus kemudian diayak dengan ukuran 20 mesh. Proses demineralisasi dilakukan dengan tujuan untuk memisahkan mineral yang terkandung dalam serbuk ikan papuyu. Kitin kasar dicampur dengan larutan $\mathrm{HCl} 1 \mathrm{~N}$ dan diaduk selama 40 jam. Perbandingan kitin kasar dan larutan $\mathrm{HCl} 1 \mathrm{~N}$ yang digunakan adalah 1:15. Larutan kitin kasar dan $\mathrm{HCl}$ kemudia disaring dan dicuci dengan aquades hingga netral. Tahap selanjutnya adalah deproteinasu pada kitin yang bertujuan untuk memisahkan protein. Tahap deproteinasi dilakukan dengan cara merendam larutan kitin tersebut dengan menggunakan larutan $\mathrm{NaOH} 5 \%(\mathrm{~b} / \mathrm{v})$ dengan perbandingan 1:12 selama 24 jam. Tahap terakhir adalah proses deasetilasi yang dilakukan dengan cara memanaskan kitin pada suhu 950C sambil diaduk selama 2 jam dalam larutan $\mathrm{NaOH} 70 \%$ dengan perbandingan 1:10. Campuran larutan tersebut kemudian didiamkan selama 72 jam dan disaring. Endapan kitosan yang diperoleh kemudian dinetralkan dengan akuades. 


\section{Pembuatan Edible Film}

Tahap pertama pati jagung sebanyak $6 \mathrm{~g}$ dimasukkan ke dalam gelas beker $100 \mathrm{~mL}$ lalu ditambahkan akuades sebanyak $100 \mathrm{~mL}$. Setelah itu, dipanaskan pada suhu gelatinasi pati yaitu $70^{\circ} \mathrm{C}$ dan dilakukan pengadukan hingga terbentuk larutan kental berwarna putih. Kitosan dilarutkan dalam larutan asam asetat $1 \%$. Selanjutnya kitosan dicampur dalam larutan pati dan diaduk dengan selama 20 menit sambil dipanaskan pada hotplate pada suhu $60^{\circ} \mathrm{C}$. Gliserol ditambahkan ke dalam campuran sebanyak $4 \mathrm{~mL}$ hingga homogen. Larutan dituang ke dalam cetakan kaca berdiameter $20 \mathrm{~cm}$. Selanjutnya dikeringkan di dalam oven selama 24 jam pada suhu $40^{\circ} \mathrm{C}$. Setelah kering edible film dilepas dari cetakan dan dilanjutkan analisis.

\section{Analisis Fourier Transformed Infra-Red (FTIR)}

Fungsinya sebagai radiasi yang diinterferensikan dengan radiasi inframerah agar sinyal radiasi inframerah yang diterima oleh detector secara utuh dan lebih baik. Edible film dari pati jagung dengan penambahan kitosan dan gliserol dianalisa gugus fungsi yang terkandung pada edible film yang dihasilkan. Sampel diletakkan didalam set holder, lalu dicari spectrum yang sesuai. Hasil yang akan didapatkan dilakukan difraktogram hubungan antara bilangan gelombang dengan intensitas. Spektrum FTIR kemudian direkam menggunakan spektrofotometer pada suhu ruang.

\section{Kuat tarik (Tensile Strength) dan Pemanjangan saat Pemutusan (Elongation at Break)}

Kekuatan tarik pada penelitian ini diuji dengan menggunakan Torsee's Electronic System Universal Testing Machine dengan kecepatan 20 mm/menit dan beban 100 kgf. Setiap sampel dicetak sebanyak 2 buah dan diambil ratarata dari pengujian tersebut. Pemanjangan pada saat putus menunjukkan perubahan panjang film maksimum saat memperoleh gaya tarik sampai film putus dibandingkan dengan panjang awalnya. Persentase pemanjangan ditentukan berdasarkan pada penambahan panjang film pada saat putus. Nilai pemanjangan (\% elongation at break) diukur berdasarkan rumus:

$$
\begin{aligned}
& \text { \%Elongation at break }=\frac{\text { stroke }}{l o} \times 100 \% \ldots(1) \\
& \begin{array}{cl}
\text { Keterangan: Stroke } & =\text { regangan }(\mathrm{mm}) \\
\text { lo } & =\text { panjang sampel mula-mula }(\mathrm{mm})
\end{array}
\end{aligned}
$$




\section{Struktur Morfologi}

Pengujian struktur morfologi dilakukan dengan menggunakan Scanning Electron Microscope (SEM). SEM merupakan mikroskop yang bekerja berdasarkan prinsip emisi elektron pada sampel yang diiradiasi. Sehingga sampel yang akan diuji harus berupa sampel kering. Sampel diletakkan pada set holder dengan perekat ganda, lalu dilapisi dengan logam emas dalam keadaan vakum. Kemudian, sampel dimasukkan dalam alat SEM JEOL JSM-6360LA, gambar topografi diamati dan dilakukan perbesaran 5000 kali.

\section{HASIL DAN PEMBAHASAN}

\section{Analisis Gugus Fungsional dengan FTIR}

FTIR digunakan untuk mengetahui interaksi antara komponen film serta jenis ikatan yang terjadi.

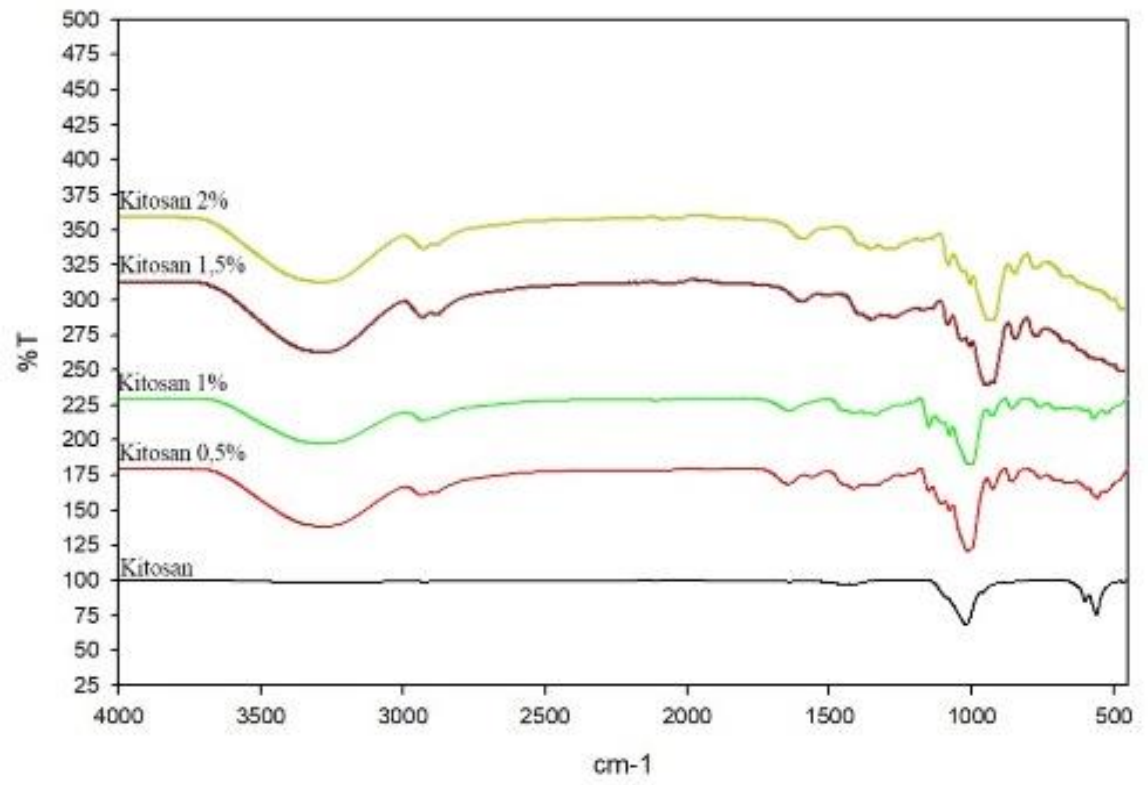

Gambar 1. Gelombang FTIR pada konsentrasi Kitosan yang Berbeda

Berdasarkan Gambar 1. dapat diketahui bahwa pada puncak yang besar yaitu mendekati $3290 \mathrm{~cm}^{-1}$, dimana terdapat gugus hidroksil yaitu OH yang terbentuk akibat adanya komposisi pati dan gliserol. Pada puncak sekitar 2900 $\mathrm{cm}^{-1}$ terdapat gugus $-\mathrm{CH}_{2}$. Selain itu gugus $-\mathrm{CH}_{2}$ terbentuk pada puncak sekitar $1400 \mathrm{~cm}^{-1}$ pada edible film. Pada puncak paling tinggi yaitu sekitar $1019 \mathrm{~cm}^{-1}$ terdapat gugus karbon yaitu $\mathrm{C}=\mathrm{O}$ yang menunjukkan bahwa adanya kitosan pada edible film. Pada nilai puncak terakhir yaitu sekitar $551 \mathrm{~cm}^{-1}$ terdapat gugus $\mathrm{C}-\mathrm{H}$ dari molekul kitosan. Hasil tersebut menunjukkan bahwa ikatan 
hidrogen intermolekul antara pati dan kitosan ketika dicampurkan pada edible film.

\section{Elongation at Break (Pemanjangan Pemutusan)}

Pemanjangan pemutusan pada edible film menunjukkan fleksibilitas dan kapasitas pemanjangan dari film tersebut. Penentuan nilai presentase pemanjangan pemutusan ditentukan ketika film putus pada pengujian kuat tarik. Selain itu nilai perubahan ditentukan oleh pemanjangan dari film tersebut untuk meregang. Pemanjangan pemutusan film dari edible film pati jagung dengan penambahan kitosan sisik ikan papuyu meningkat dengan penambahan konsentrasi kitosan. Presentase pemanjangan pemutusan edible film disajikan pada gambar 2 .

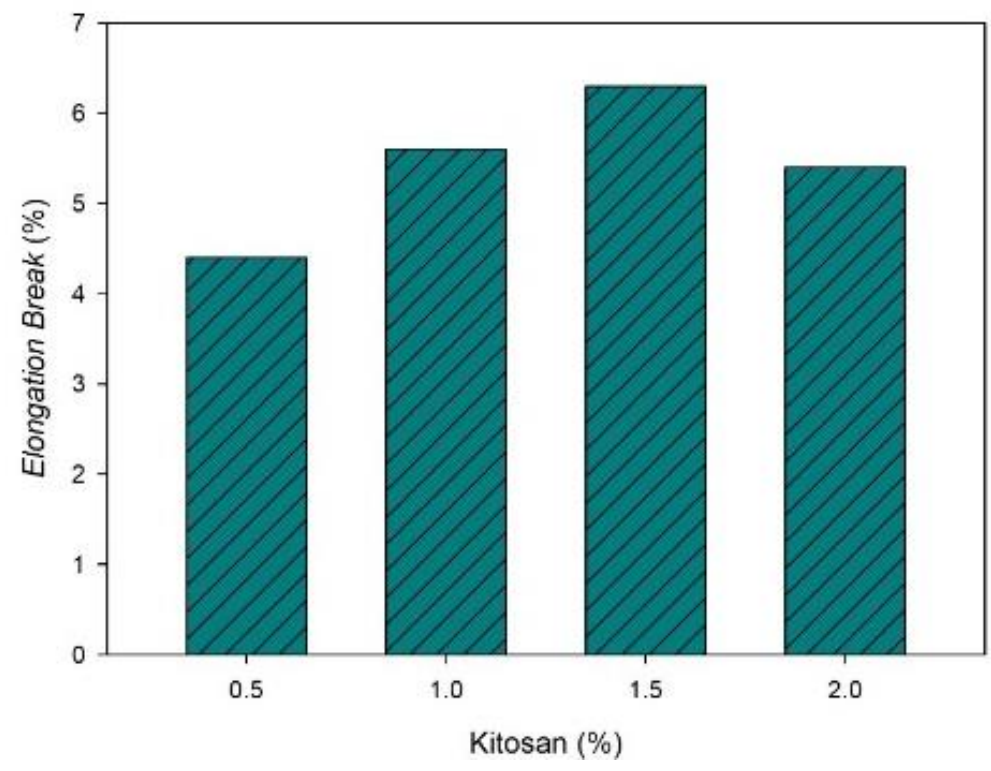

Gambar 2. Presentase Pemanjangan Pemutusan Edible Film

Berdasarkan gambar 2, nilai elongasi meningkat seiring penambahan kitosan dan mengalami penurunan pada penambahan kitosan $2 \%$. Hal ini menurut Kelnar (2013) kombinasi kitosan meningkatkan kekakuan akibat efek penguatan kitosan pada film. Hal ini dapat diasumsikan bahwa tingginya kompetensi dari interaksi polar antara gugus amino dari kitosan dan gugus hidroksil molekul pati yang menimbulkan kekakuan film. Peningkatan fleksibilitas film pada konsentrasi kitosan yang lebih tinggi dapat disebabkan oleh interaksi rantai polimer-plasticizer yang memfasilitasi geser rantai dan dengan demikian membantu meningkatkan fleksibilitas keseluruhan dan mobilitas rantai (Ren, 2017). 


\section{Tensile Strength (Kuat tarik)}

Kuat tarik yang tinggi secara umum diperlukan, tetapi nilai-nilai deformasi harus disesuaikan dengan aplikasi film yang dimaksud. Berikut merupakan hasil kuat tarik yang didapat pada gambar 3 .

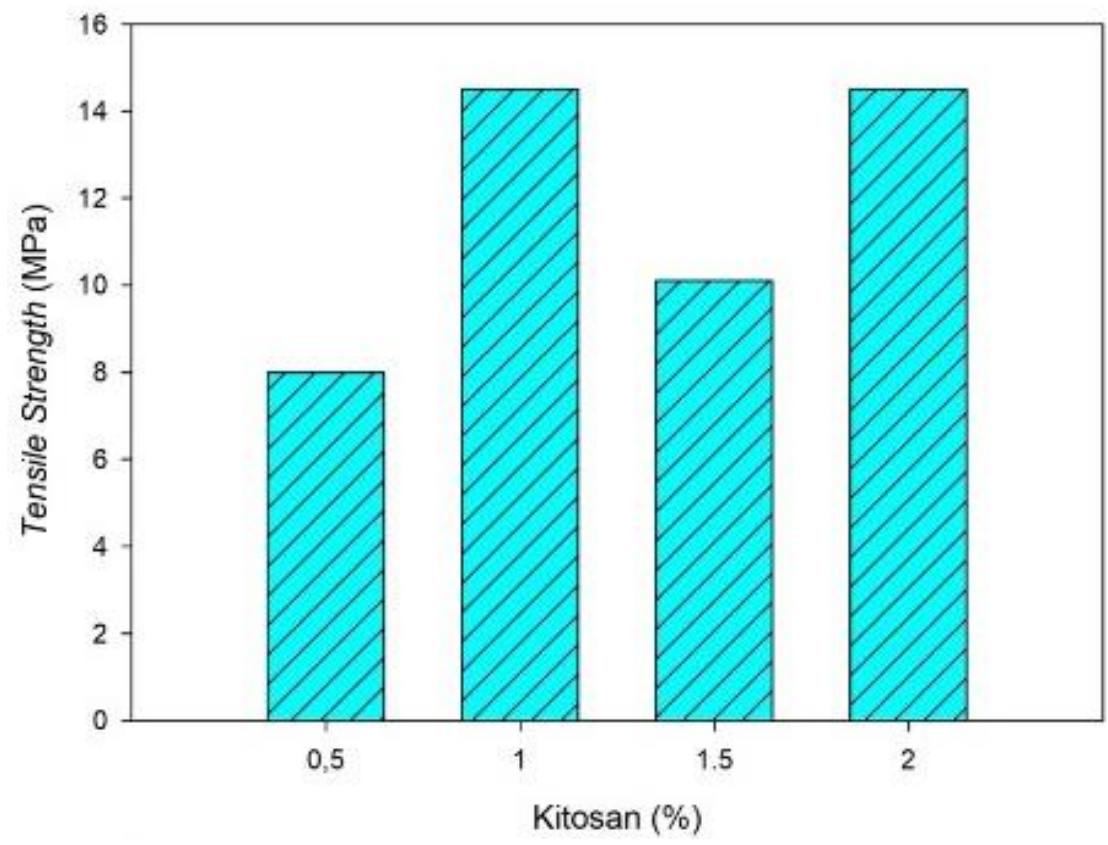

Gambar 3. Nilai Kuat tarik Edible Film

Pada gambar menunjukkan bahwa kuat tarik meningkat seiring dengan penambahan kitosan hal ini karena tingginya formasi intermolekul ikatan antara hidrogen dan $\mathrm{NH}_{3}{ }^{+}$dari rantai kitosan dan $\mathrm{OH}-$ dari pati. Gugus amino $\left(\mathrm{NH}_{2}\right)$ dari kitosan terprotonasi $\mathrm{ke} \mathrm{NH}_{3}{ }^{+}$dalam larutan asam asetat, sedangkan struktur kristal pada molekul pati dihancurkan dengan proses gelatinisasi, menghasilkan gugus $\mathrm{OH}^{-}$sehingga dengan mudah terbentuk ikatan hidrogen dengan $\mathrm{NH}_{3}{ }^{+}$dari kitosan (Bourtoom, 2008) tetapi pada penambahan kitosan 1,5\% nilai kuat tarik mengalami penurunan karena ikatan $\mathrm{OH}-$ dengan $\mathrm{NH}_{3}{ }^{+}$tidak terikat dengan sempurna. Hal ini disebabkan karena ukuran partikel kitosan yang cukup besar dan tidak terlarut sempurna saat gelatinisasi. Menurut (Ban, 2005) faktor penting yang dapat mempengaruhi sifat fisik adalah affinitas antara komponen penyusunnya. Affinitas merupakan suatu fenomena dimana suatu atom atau molekul tertentu memiliki kecenderungan untuk bersatu dan berikatan.

\section{Struktur Morfologi dengan SEM (Scaning Electron Microscopy)}

Analisa SEM bertujuan untuk mengetahui struktur morfologi dari edible film. Gambar 4 menyajikan hasil uji SEM. 

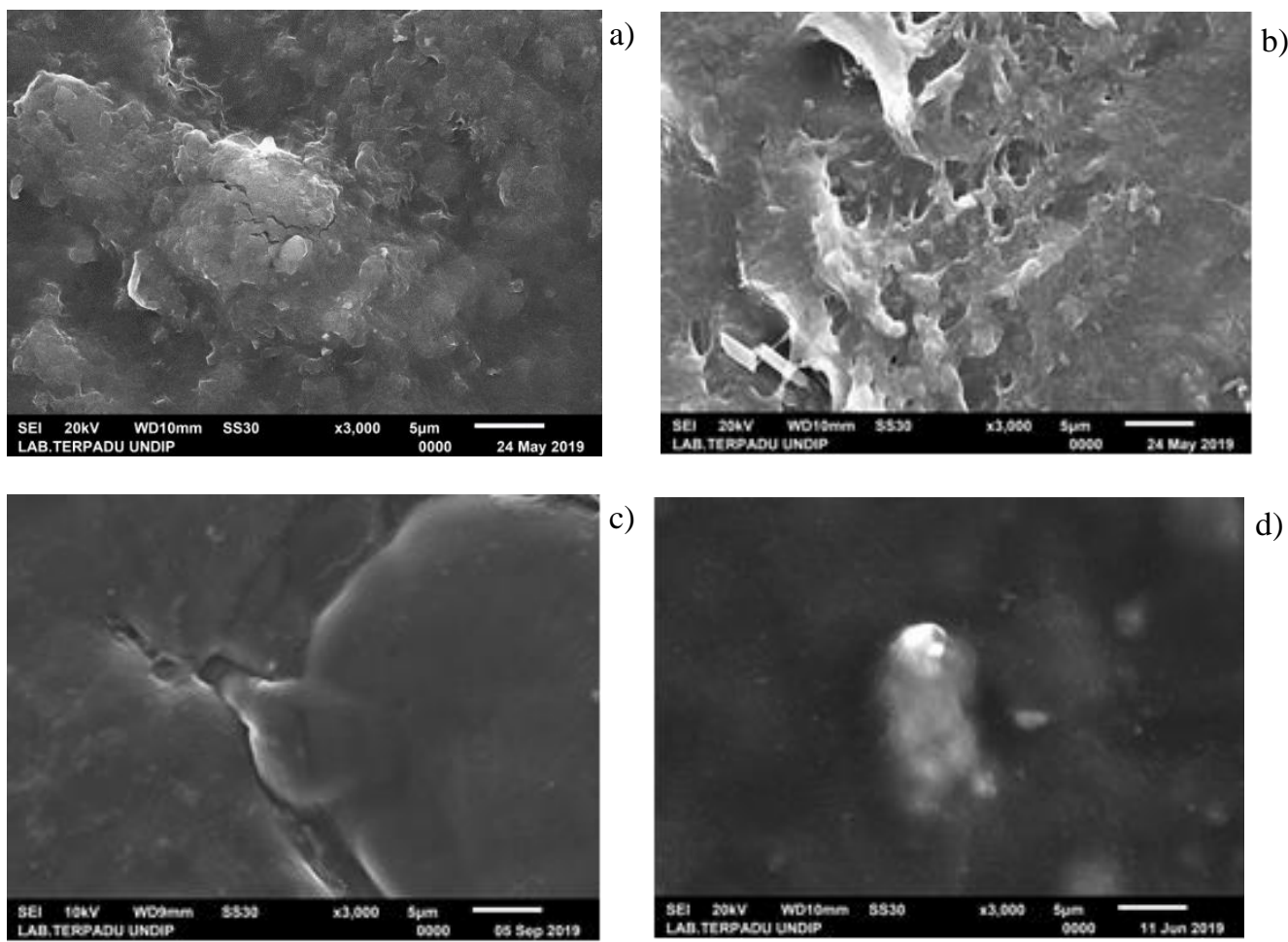

Gambar 4. Hasil Uji SEM pada Edible Film Pati-Kitosan: (a) Penambahan Kitosan $0,5 \%$ (b) Penambahan Kitosan 1\% (c) Penambahan Kitosan 1,5\% dan (d) Penambahan Kitosan 2\%

Berdasarkan Gambar 4. memperlihatkan bahwa struktur film pada konsentrasi kitosan 0,5 g dan $1 \mathrm{~g}$ mempunyai pori-pori. Hal tersebut terjadi karena interaksi kimia yang kurang baik antara pati jagung dan kitosan. Hal ini dipengaruhi oleh kitosan yang digunakan memiliki ukuran yang besar sehingga kitosan tidak dapat terlarut sempurna. Kitosan konsentrasi 2 g memiliki poripori yang cukup rapat menunjukkan bahwa kitosan membentuk interkasi kimia yang baik dengan pati jagung.

\section{KESIMPULAN}

Variasi penambahan kitosan berpengaruh terhadap sifat kimia, mekanik dan struktur morfologi pada edible film. Pada puncak $3290 \mathrm{~cm}^{-1}$ dan $1019 \mathrm{~cm}^{-1}$ menandakan bahwa edible film mengandung gugus hidroksil dan gugus karbon yang menandakan adanya pati, gliserol dan kitosan. Elastisitas tertinggi terdapat pada edible film dengan konsentrasi $1,5 \%$ dan kuat tarik dengan nilai tertinggi pada konsentrasi $1 \%$ dan $2 \%$ hal ini karena adanya interaksi polar antara gugus amino pada kitosan dan gugus hidroksil pada pati. Struktur morfologi pada 
edible film menunjukkan bahwa kitosan tercampur sempurna pada variasi kitosan $2 \mathrm{~g}$.

\section{UCAPAN TERIMAKASIH}

Penulis mengucapkan terimakasih kepada PT. Indofood Sukses Makmur Tbk. yang telah mendanai penelitian ini melalui dana Hibah Indofood Riset Nugraha tahun 2018.

\section{DAFTAR PUSTAKA}

Antoniou, J., Liu, F., Majeed, H. dan Zhong, F. 2015. Characterization of tara gum edible films incorporated with bulk chitosan and chitosan nanoparticles: A comparative study. Food Hydrocolloids, 44, 309-319.

Asnia, Mira dan Rosmasari Marisa. 2017. Potensi Kitosan Dari Sisik Ikan Papuyu Sebagai Koagulan Alami Untuk Menurunkan Kadar Logam Besi (Fe) Pada Air Sumur Masyarakat Di Martapura. Universitas Lambung Mangkurat.

Ban, W. 2005. Improving The Physical and Chemical Functionally of StarchDerived Films with Biopolymers. Journal of Applied polymer Science, 10, 118-129.

Basiak, E., Lenart, A. \& Debeaufort, F. 2017. Effect of starch type on the physico-chemical properties of edible films. International Journal of Biological Macromolecules, 98, 348-356.

Bourtoom, T., M.S, Chinnan 2008. Preparation and Properties of Rice StarchChitosan Blend Biodegradable Film. LWT-Food Sci Technology, 41, 16331641.

Dutta, P. K., Tripathi, S., Mehrotra, G. K. And Dutta, J 2009. Perspectives for Chitosan Based Antimicrobial Films in Food Applications. Food Chemistry 114, 4, 1173-1182.

Fernandez-Saiz, P., Lagaron, J. M., dan Ocio, M. J 2009. Optimization of The Biocide Properties of Chitosan for Its Application in The Design of Active Films of Interest in The Food Area. Food Hydrocolloids 23, 3, 913-921.

Forssell, P., R. L., M. Lahelin, P. Myllärinen 2002. Oxygen Permeability of Amylose and Amylopectin Films. Carbohydr. Polym, 47, 125-129.

Imran, M., Revol-Junelles, A.-M., Martyn, A., Tehrany, E. A., Jacquot, M., Linder, M. And Desobry, S 2010. Active Food Packaging Evolution: Transformation From Micro to Nanotechnology. Critical Reviews in Food Science and Nutrition, 799-821.

Kelnar, I., Kaprálková, L., Brožová, L., Hromádková, J. \& Kotek, J. 2013. Effect of Chitosan on The Behaviour of The Wheat B-Starch Nanocomposite. Industrial Crops and Products, 46, 186-190.

Ren, Lili., X. Y., Jiang Zhou, Jin Tong, Xingguang Su 2017. Influence of Chitosan Concentration on Mechanical and Barrier Properties of Corn Starch/Chitosan Films. International Journal of Biological Macromolecules, $105,1636-1643$. 
Mathew, S. A. A., T. E 2008. Characterisation of Ferulic Acid Incorporated Starch-Chitosan Blend Films. Food Hydrocolloids, 22, 826-835.

Othman, S. H. 2014. Bio-nanocomposite Materials for Food Packaging Applications: Types of Biopolymer and Nano-Sized Filler. Agriculture and Agricultural Science Procedia 2, 296-303.

Othman, S. H., Shapi'i R. A. 2016. Effect of Concentration of Chitosan on The Mechanical, Morphological and Optical Properties of Tapioca Starch Film. International Food Research Journal, 23.

Yang Sy, L. C., Wu Jy, Et al.Yang Sy, Liu Ci, Wu Jy, Et al 2008. Improving the processing ability and mechanical strength of starch/poly(vinyl alcohol) blends through plasma and acid modification. Macromol Symp, 272, 150155. 